\title{
Anti-vascular endothelial growth factor treatment in diabetic macular edema
}

This article was published in the following Dove Press journal:

Therapeutics and Clinical Risk Management

2 September 2016

Number of times this article has been viewed

\section{Moosang Kim}

Department of Ophthalmology, School of Medicine, Kangwon National University, Chuncheon, Korea
Correspondence: Moosang Kim Department of Ophthalmology, School of Medicine, Kangwon National University Hospital, Baengnyeong-ro I56, Chuncheon, Kangwon, 200-722, Korea

Tel +82 332582014

Fax +82 29667340

Email kimmoo-79@hanmail.net

\section{Dear editor}

We read with great interest the article titled "Clinical effects and safety of treating diabetic macular edema with intravitreal injection of ranibizumab combined with retinal photocoagulation" by Yan et al. ${ }^{1}$ We congratulate the authors for this well-organized study and would like to contribute to their findings.

The Early Treatment Diabetic Retinopathy Study demonstrated that focal laser for diabetic macular edema (DME) effectively halved the percentage of eyes that experienced vision loss and doubled the percentage of eyes that achieved visual gain. ${ }^{2}$ Until the past decade, focal laser photocoagulation was the standard of care for treating DME.

The development of anti-vascular endothelial growth factor (VEGF) therapy has revolutionized the treatment for DME. ${ }^{3,4}$ The first prospective study to compare laser monotherapy with combined laser and anti-VEGF was undertaken by the DRCRnet. ${ }^{5}$ Intravitreal ranibizumab (Lucentis; Genentech, Inc., South San Francisco, CA, USA) with prompt vs deferred focal/grid laser was shown to be superior to laser alone. Subsequently, the RESTORE study directly compared ranibizumab monotherapy, or in combination with focal laser, with focal laser alone. ${ }^{6}$ It demonstrated that ranibizumab monotherapy or the combination was superior to laser monotherapy in vision gains and in reducing central retinal thickness. Furthermore, at 1 year, no differences were detected between the ranibizumab and ranibizumab/laser arms.

Although anti-VEGF is effective for most patients, refractory DME occurs in one-quarter of eyes despite treatment. Inflammation plays a significant role in the pathophysiology of diabetes. ${ }^{7}$ Evidence has suggested that the release of inflammatory cytokines, including interleukin- $1 \beta$ and tumor necrosis factor- $\alpha$, contributes to dysfunction of endothelial tight junctions, resulting in macular edema. ${ }^{8-11}$

Consistent with these findings, steroids have been shown to be effective for treating macular edema. ${ }^{12,13}$ All steroid formulations, however, accelerate cataract formation, and they also carry the risk of increased intraocular pressure.

It is an exciting era in the treatment of DME, with effective therapies shifting our treatment paradigms. With a growing population affected by diabetes, the demand for better treatments for DME will continue to rise.

\section{Disclosure}

The author reports no conflicts of interest in this communication. 


\section{References}

1. Yan P, Qian C, Wang W, Dong Y, Wan G, Chen Y. Clinical effects and safety of treating diabetic macular edema with intravitreal injection of ranibizumab combined with retinal photocoagulation. Ther Clin Risk Manag. 2016;12:527-533.

2. Photocoagulation for diabetic macular edema. Early treatment diabetic retinopathy study report number 1 . Early treatment diabetic retinopathy study research group. Arch Ophthalmol. 1985;103(12):1796-1806.

3. Rajendram R, Fraser-Bell S, Kaines A, et al. A 2-year prospective randomized controlled trial of intravitreal bevacizumab or laser therapy (BOLT) in the management of diabetic macular edema: 24-month data: report 3. Arch Ophthalmol. 2012;130(8):972-979.

4. Do DV, Nguyen QD, Shah SM, et al. An exploratory study of the safety, tolerability and bioactivity of a single intravitreal injection of vascular endothelial growth factor trap-eye in patients with diabetic macular oedema. Br J Ophthalmol. 2009;93(2):144-149.

5. Diabetic Retinopathy Clinical Research Network, Elman MJ, Aiello LP, et al. Randomized trial evaluating ranibizumab plus prompt or deferred laser or triamcinolone plus prompt laser for diabetic macular edema. Ophthalmology. 2010;117(6):1064-1077.

6. Mitchell P, Bandello F, Schmidt-Erfurth U, et al. The RESTORE study: ranibizumab monotherapy or combined with laser versus laser monotherapy for diabetic macular edema. Ophthalmology. 2011;118(4): 615-625.
7. Antonetti DA, Klein R, Gardner TW. Diabetic retinopathy. $N$ Engl $J$ Med. 2012;366(13):1227-1239.

8. Grigsby JG, Cardona SM, Pouw CE, et al. The role of microglia in diabetic retinopathy. J Ophthalmol. 2014;2014:705783.

9. Ibrahim AS, El-Remessy AB, Matragoon S, et al. Retinal microglial activation and inflammation induced by amadori-glycated albumin in a rat model of diabetes. Diabetes. 2011;60(4):1122-1133.

10. Joussen AM, Poulaki V, Mitsiades N, et al. Nonsteroidal anti-inflammatory drugs prevent early diabetic retinopathy via TNF-alpha suppression. FASEB J. 2002;16(3):438-440.

11. Funatsu H, Noma H, Mimura T, Eguchi S, Hori S. Association of vitreous inflammatory factors with diabetic macular edema. Ophthalmology. 2009;116(1):73-79.

12. Gillies MC, Sutter FK, Simpson JM, Larsson J, Ali H, Zhu M. Intravitreal triamcinolone for refractory diabetic macular edema: two-year results of a double-masked, placebo-controlled, randomized clinical trial. Ophthalmology. 2006;113(9):1533-1538.

13. Martidis A, Duker JS, Greenberg PB, et al. Intravitreal triamcinolone for refractory diabetic macular edema. Ophthalmology. 2002;109(5): 920-927.

Dove Medical Press encourages responsible, free and frank academic debate. The content of the Therapeutics and Clinical Risk Management 'letters to the editor' section does not necessarily represent the views of Dove Medical Press, its officers, agents, employees, related entities or the Therapeutics and Clinical Risk Management editors. While all reasonable steps have been taken to confirm the content of each letter, Dove Medical Press accepts no liability in respect of the content of any letter, nor is it responsible for the content and accuracy of any letter to the editor.

\section{Dovepress}

\section{Publish your work in this journal}

Therapeutics and Clinical Risk Management is an international, peerreviewed journal of clinical therapeutics and risk management, focusing on concise rapid reporting of clinical studies in all therapeutic areas, outcomes, safety, and programs for the effective, safe, and sustained use of medicines. This journal is indexed on PubMed Central, CAS,
EMBase, Scopus and the Elsevier Bibliographic databases. The manuscript management system is completely online and includes a very quick and fair peer-review system, which is all easy to use. Visit http://www.dovepress.com/testimonials.php to read real quotes from published authors. 